УДК 658.114.5

\title{
УПРАВЛІННЯ РОЗВИТКОМ ІНТЕГРОВАНИХ КОРПОРАТИВНИХ СТРУКТУР НА ОСНОВІ ЗБАЛАНСОВАНОЇ СИСТЕМИ ПОКАЗНИКІВ
}

\author{
Чухлата Ж.Г., ст. викладач (НА НГУ)
}

У статті розкрито питання вдосконалення методичного підходу до регламентації діяльності корпоративних структур зі складною архітектурною побудовою на базі застосування концепції збалансованої системи показників. Запропоновано підхід до інтегращії иієї системи при використанні мереж Петрі. Досліджено, щзо визначення принцииів стратегічного управління інтегрованої корпоративної системи базується на організащії ї̈ стратегічного обліку $і$ звітності в системі менеджменту.

Ключові слова: показник, структура, збалансована система, інтеграція, менеджмент, концепція

\section{УПРАВЛЕНИЕ РАЗВИТИЕМ ИНТЕГРИРОВАННЫХ КОРПОРАТИВНЫХ СТРУКТУР НА ОСНОВЕ СБАЛАНСИРОВАННОЙ СИСТЕМЫ ПОКАЗАТЕЛЕЙ}

\author{
Чухлата Ж..Г., ст. преподаватель (НА НГУ)
}

В статье раскрыты вопросы совершенствования методического подхода $\kappa$ регламентачии деятельности корпоративных структур со сложным архитектурным построением на базе применения концепџии сбалансированной системы показателей. Предложен, подход к интеграчии этой системь при использовании сетей Петри. Исследовано, что определение принщипов стратегического управления интегрированной корпоративной системы базируется на организаџии стратегического учета и отчетности в системе менеджмента.

Ключевые слова: показатель, структура, сбалансированная система, интеграция, менеджмент, концепџия

\section{MANAGEMENT DEVELOPMENT OF INTEGRATED THE CORPORATE STRUCTURES BASED ON BALANCED SCORECARD}

\section{Chuhlata.G., senior lecturer ( National Academy of National guard of Ukraine)}

In conditions of tough competitive environment, it is pertinent to integration of enterprises, resulting in the formation of complex logistic chains and cooperation ties between enterprises. These chains, for its normal functioning require appropriate management system based on balanced scorecard. Chain logistics and cooperative relations between enterprises are often reflected in the form of integrated corporate structures.

For disclosure purpose, the article proposes the use of Petri nets apparatus. The 
feasibility of its application due to the need to address selected objectives of the study in the dynamic aspect (the sequence of events and transitions).

The basis for the implementation of the strategy and the work generated through the subsystem of operational management can only make accounting system of integrated corporate structures. The feature of this system should be its focus on the recognition of strategic information, which is achieved by a specific sequence of actions.

First, event data, and transitions are used to justify the principles for the use of BSC in IKS. Feature of this scheme is the use of dehorn approach to the coordination of the principles of the strategic management (implemented by transitions $t 6, t 8, T C$ ) operation which involves recompletion of the cycle of development of system principles).

So, this study presents an approach to the construction of the loop of strategic management of integrated corporate structures, a feature which is to focus on balanced scorecard and nomenclature of the strategic account. However, further studies should more clearly define the components of strategy maps (pBSC) for their compliance with the architecture of $X$ (the position of the RCA).

Key words: rate, structure, balanced system, integration, management, concept.

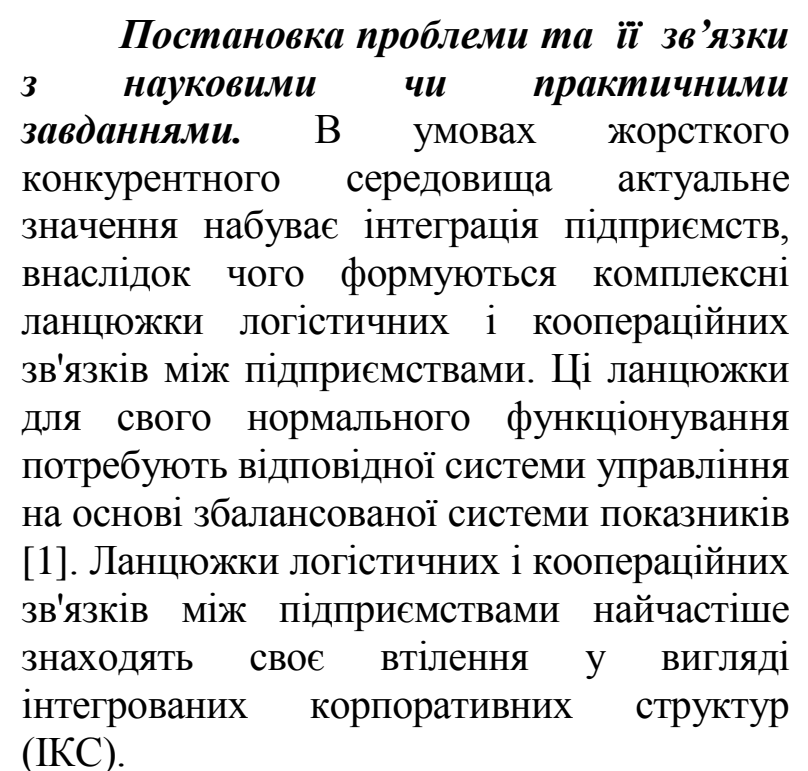

Аналіз останніх досліджень $i$ публікацій та виділення невирішених частин загальної проблеми. В роботах таких авторів, як Іванова Ю.Б., Каплана Р., Радаєва В.В., Третьяк О.А., Флігстіна Н. та iн. [2-6] розглянуто питання управління інтеграційним розвитком підприємств. Разом 3 тим, залишається відкритим питання формування інструментарію для механізму управління інтегрованих корпоративних структур. В рамках обговорення даної проблеми дуже часто орієнтуються на впровадження збалансованої системи показників (Balansed Score Card, BSC [2]) в практику функціонування IКС. При цьому, напрями забезпечення взаємодії концепції $\mathrm{BSC} 3$ системою стратегічного управління складних корпоративних структур з різним ступенем інтеграційних обмежень, залишаються поза зоною уваги вченихекономістів.

Отже, метюю статті $€$ формування моделі стратегічного управління інтегрованих корпоративних структур зі складною архітектурною побудовою на базі застосування концепції збалансованої системи показників.

\section{Виклад основного матеріалу} дослідження. Для розкриття мети статті запропоновано використання апарата мереж Петрі. Доцільність його застосування обумовлюється необхідністю розгляду обраної мети дослідження в динамічному аспекті (послідовності подій і переходів). При цьому передбачається використання кількох формалізованих мережами Петрі схем, що мають загальні елементи, такі як:

- рв - позиція, яка відображує з'ясування менеджментом IКC наявності проблем в організації процесу операціоналізації і контролю реалізації стратегіï;

- pS - відображення всіх наявних у IKC стратегічних альтернатив розвитку та параметрів узгодження стратегічних цілей iï учасників; 
- pBSC - елементи збалансованої системи показників, що представляють собою набори ключових факторів успіху та показників ефективності IKC;

- pKA - представлені у формалізованому вигляді (наприклад, у вигляді моделі Захмана) архітектура i організаційно-структурна побудова IКС;

- $\mathrm{pK}, \mathrm{p \Gamma} \mathrm{-} \mathrm{позиції} \mathrm{відображають}$ відповідно необхідність остаточної перевірки відповідності сформованої системи стратегічного управління запитами суб'єкта управління і готовність цієї системи до експлуатації;

- tC, tK - відповідно стартовий (свідчать про необхідність повторного проходження всіх запропонованих етапів) i кінцевий переходи (що свідчить про інтеграції системи стратегічного управління і BSC).

Спочатку дані події i переходи використовуються для обгрунтування принципів використання BSC в IКC, що представлено на рис. 1. Особливістю даної схеми $\epsilon$ застосування двохрівневого підходу до узгодження принципів організації стратегічного управління (реалізовано переходами t6, t8, tC) спрацювання яких передбачає повторне проходження циклу розробки системи принципів). Крім цього, реалізація зазначеної схеми орієнтується на ряд наступних елементів. Для першого циклу формування принципів i правил стратегічного управління IKC: $\mathrm{t} 1$ - розподіл функцій стратегічного управління та встановлення відповідальних за їх виконання; p1 - формалізоване подання організаційно-структурної декомпозиції інтегрованої освіти; t2 - співвіднесення ключових факторів успіху, стратегічних цілей i показників 3 різними рівнями архітектоніки IКС; р2 - розроблені для вищого менеджменту IКС (представлених у вигляді стратегічних бізнес-одиниць) система параметрів інтегрованої стратегії; t3 - формалізація стратегії через іiі подання у вигляді стратегічної карти BSC; p3 розроблений варіант корпоративної стратегічної карти; t4 - каскадування елементів стратегічної карти за рівнями ієрархії (архітектури) IКС.

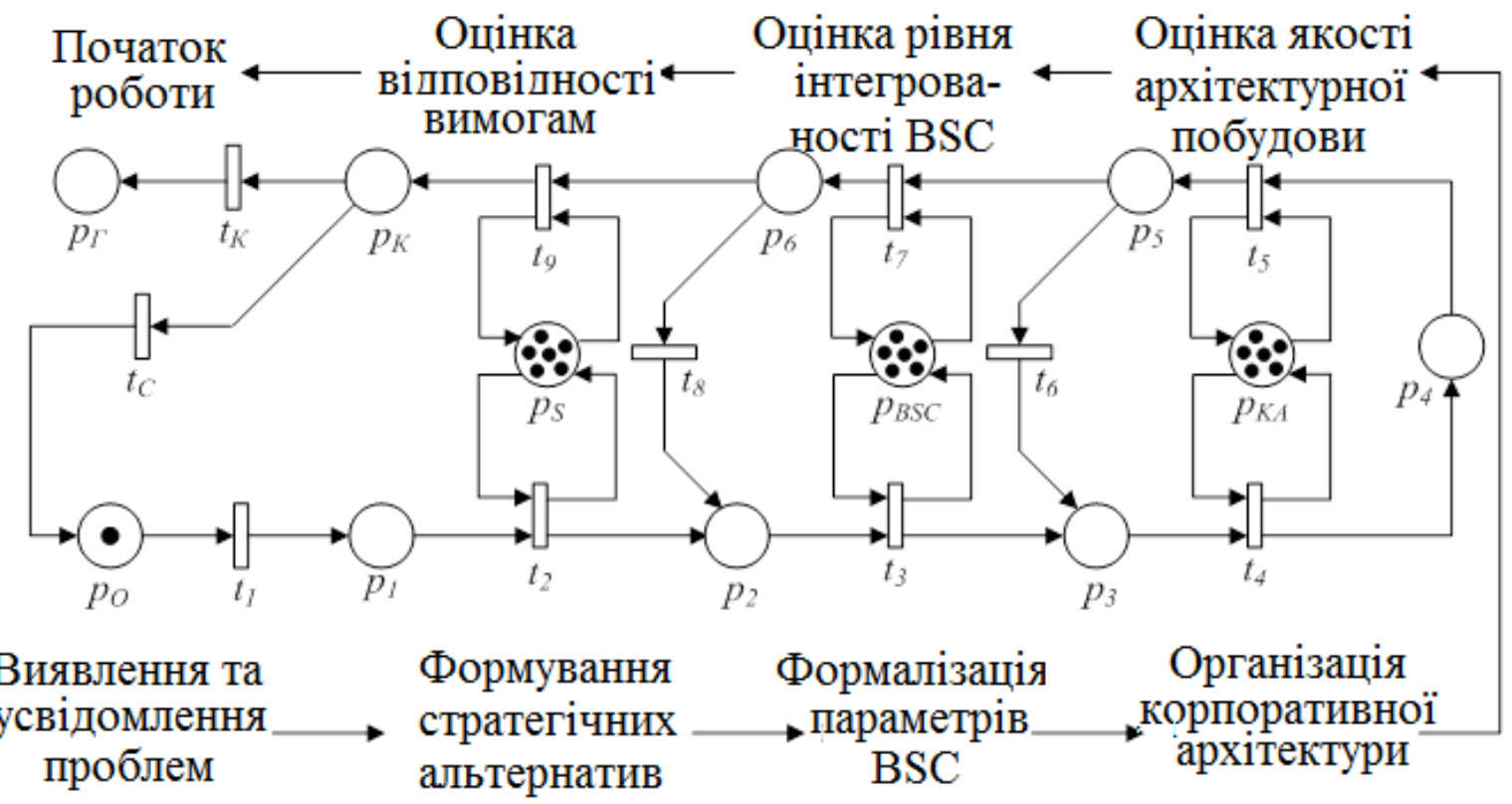

Рис. 1. Визначення принщипів стратегічного управління інтегрованої корпоративної системи

Для другого рівня: p4 - затверджений забезпечення відповідності допоміжних варіант стратегії IКС в рамках перспектив процесів розподілу ролей учасників IКС; p5 збалансованої системи показників; t5 - - регламенти управління функціональними 
службами і допоміжними процесами IKC; t7 - розробка системи контролю за досягненням учасниками IКC планових показників; 19 - коригування відповідності функцій управління IКС 3 параметрами стратегічної карти BSC.

Після означеного на рис. 1 визначення принципів представлення стратегії ІКС в циклі BSC слід визначити основні напрями реалізації та контролю за реалізацією цієї стратегіï. Тут найбільш оптимальним варіантом буде орієнтація на представлену на рис. 2 послідовність.

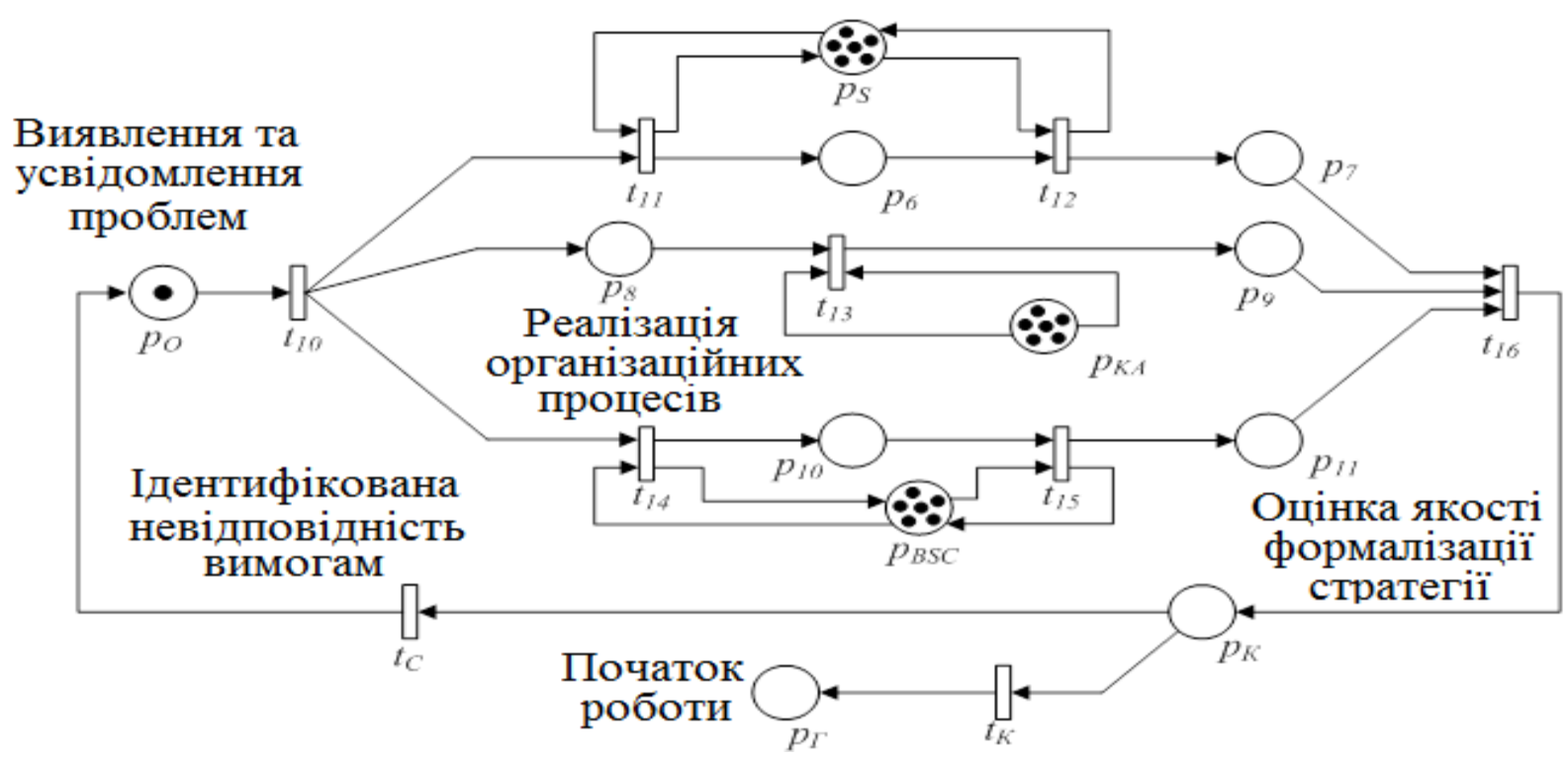

Рис. 2. Визначення параметрів підсистеми оперативного управління для забезпечення реалізачії стратегічних альтернатив IКС

Основу представлення параметрів системи оперативного управління при реалізації стратегії ІКС складають наступні події і переходи: 110 - визначення варіантів декомпозиції процесу реалізації стратегії; t11 - формування характеристик шаблонів поведінки учасників IКС; p6 - розподіл ролей учасників IКС та визначення прав $\mathrm{i}$ обов'язків корпоративного центру; t12 формування механізмів коригування бізнеспроцесів в ІКС (регламентація ресурсного забезпечення консолідованих процесів корпоративної логістики); р7 - система компетенцій учасників IКC, в розрізі рівнів iii архітектоніки; p8 - регламенти взаємодії підрозділів при реалізації стратегії 3 поданням параметрів системи мотивації, орієнтованої на досягнення планових значень показників; t13 - нормування індикаторів реалізації стратегії у розрізі організаційно-структурного подання IКC; p9 - розроблена і підкріплена створенням відповідних регламентів система стратегічного бюджетування IKC; $\mathrm{t} 14$ розробка системи зворотних зв'язків i формування механізмів план-фактного контролю; р10 - регламенти коригування процесів IКC; t15 - розробка документів, що регламентують функціонування BSC; p11 - формалізоване представлення системи контролінгу i стратегічного моніторингу IKC, ; t16 - оцінка якості розробки та декомпозиції стратегії в рамках прийнятих в ІКС стандартів та розуміння якості стратегії.

Основу для реалізації стратегії i роботи сформованої за допомогою представленої на рис. 2 схеми підсистеми оперативного управління може складати тільки система бухгалтерського обліку IКС. Особливістю даної системи повинна стати ii орієнтація на відображення в обліку стратегічної інформації, що досягається представленою на рис. 3 послідовністю дій.

Реалізація цієї послідовності припускає наявність наступних подій i 
переходів: t17 - визначення стратегічних завдань розвитку обліково-аналітичного забезпечення BSC та розвитку IKC; p12 регламенти системи стратегічного моніторингу, орієнтованого на систему ролей учасників IKC; t18 - регламентація контрольованих параметрів бізнес-процесів ІКС 3 виділенням відповідних облікових номенклатур; p13 - система управлінської звітності, адаптованої для розкриття важливої для реалізації BSC інформації про діяльність ІКС; t19 - доповнення складу показників, включених у стратегічні карти; t20 - встановлення структури звітних форм i облікових процедур для розрахунку показників бізнес-процесів; p14 регламенти контролю за траєкторією розвитку ІКС в межах виділених рівнів корпоративної ієрархії; t21 - коригування складу контрольованих показників бізнеспроцесів IKC; 222 - перегляд принципів розробки номенклатур стратегічного обліку; t23 - автоматизація каскадування показників стратегічних карт; р15 регламенти зовнішньої фінансової звітності та наказ про управлінську облікову політику; t24 - зміна підходу до відбору показників без коригування параметрів стратегіï; $\mathrm{t} 25$ - впровадження розробленої схеми стратегічного обліку.

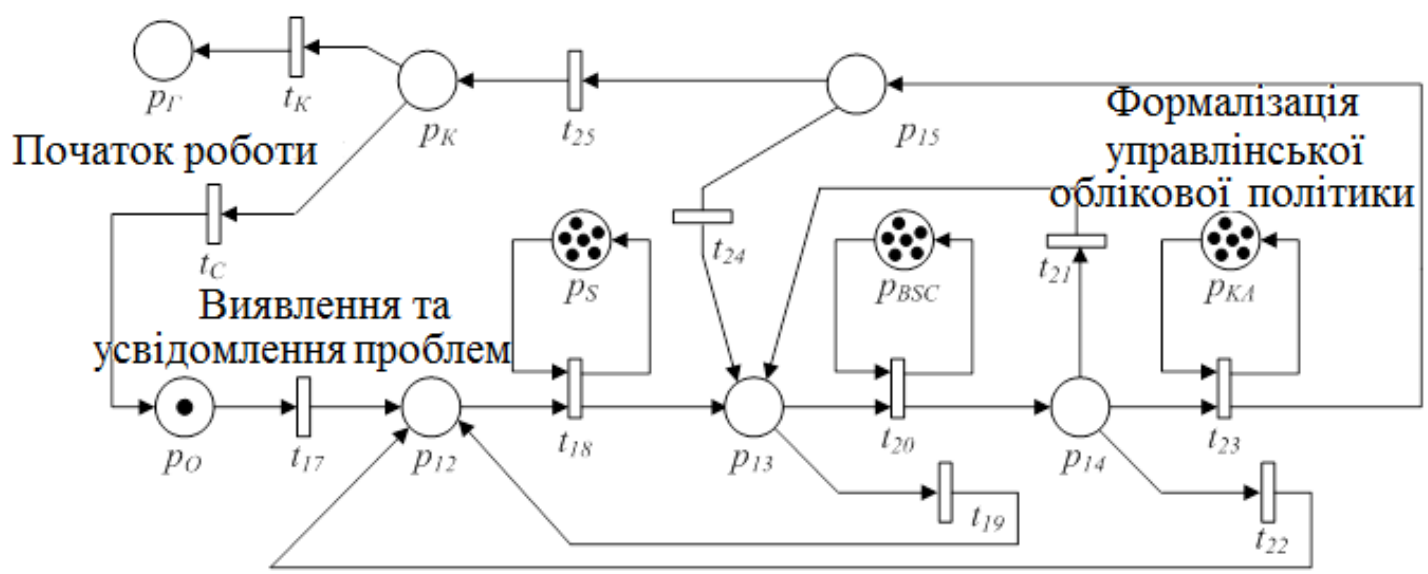

Погодження праметрів обліково-аналітичного забезпечення функціонування збалансованої системи показників

Рис. 3. Організація стратегічного обліку $і$ звітності в системі менеджменту інтегрованої корпоративної структури

Висновки. Таким чином, у даному дослідженні представлено підхід до побудови контуру стратегічного управління інтегрованими корпоративними структурами, особливістю якого $\epsilon$ орієнтація на збалансовану систему показників та номенклатури стратегічного обліку. Разом 3 тим, у подальших дослідженнях слід більш чітко визначити складові стратегічних карт (позиція рBSC) на їх відповідність елементом архітектури IКС (позиція рКА).

\section{ПЕРЕЛІК ВИКОРИСТАНИХ ДЖЕРЕЛ}

1. Каличева Н.Є. Логістичні підходи, як основа раціональної організації виробничого процесу на підприємстві/ Н.С. Каличева , В.О. Маслова// Вісник економіки транспорту і промисловості. Збір наук. праць - Харків, УкрДАЗТ, 2014. - № 47. - C. 83 - 86.

2. Іванов Ю.Б. Концепція та онтологія предметної області управління інтеграційним розвитком підприємства / Ю.Б. Іванов, А.А. Пилипенко // Економіка промисловості. - 2006. - №1(32). - С. 162 171

3. Каплан Р.Стратегическое единство: создание синергии организации с помощью ССП./ Р. Каплан, Д. Нортон. М.: ИД "Вильяс", 2006. - 384 с.

4. Радаєв В.В. Экономическая соціологія/ В.В. Радаєв. - М.: ГУ-ВШЭ, 
2005. $-438 \mathrm{c}$.

5. Третьяк О.А. Сетевые формы межфирменной кооперации / О.А. Третьяк, М.А. Румянцева // Российский журнал менеджмента. - 2003. - №2. - Том 1. - С. 25
$-50$

6. Флигстин Н. Поля, власть и социальные навыки / Н. Флигстин// Экономическая социология. - 2001. - № 4. - C. $28-55$.

УДК 658.7.01:330.522.4

\title{
ЛОГІСТИЧНІ МЕТОДИ УПРАВЛІННЯ МАТЕРІАЛЬНИМИ ЗАПАСАМИ ПІДПРИЕМСТВА: СУТНІСТЬ, РОЛЬ ТА ОСОБЛИВОСТІ ВПРОВАДЖЕННЯ
}

\author{
Швець Ю.О., к.е.н., ст. викладач, \\ Андрієнко А.О., студентка (ЗНУ)
}

В статті проаналізовано підходи вітчизняних та зарубіжних вчених до трактування сутності поняття «запаси» та оцінено їх вплив на ефективність функиіонування підприємств. Охарактеризовано класифікацію основних видів запасів та досліджено існуючі методи управління матеріальними запасами шляхом визначення їх переваг, недоліків та очінки особливості впровадження на підприємствах. На основі проведеного дослідження сформовано загальні рекомендації щзодо ефрективного впровадження на підприємствах логістичного підходу та визначено перелік факторів впливу на використання логістичних методів.

Ключові слова: логістика, матеріальні запаси, логістичний підхід, підприємство, моделі управління запасами.

\section{ЛОГИСТИЧЕСКИЕ МЕТОДЫ УПРАВЛЕНИЯ МАТЕРИАЛЬНЫМИ ЗАПАСАМИ ПРЕДПРИЯТИЯ: СУЩНОСТЬ, РОЛЬ И ОСОБЕННОСТИ ВНЕДРЕНИЯ}

\author{
Швец Ю.А., к.э.н., ст. преподаватель, \\ Андриенко А.А., студентка (ЗНУ)
}

В статье проанализированы подходы отечественных и зарубежных ученых $\kappa$ трактовке сущности понятия «запасы» и оценено их влияние на эффективность функционирования предприятий. Охарактеризована классификаичия основных видов запасов и исследованы существуюшие методы управления материальныли запасами путем определения их преимуществ, недостатков и оценки особенности внедрения на предприятиях. На основе проведенного исследования сформированы общие рекомендации по эффективному внедрению на предприятиях логистического подхода и определен перечень факторов, влияющих на использование логистических методов.

Ключевые слова: логистика, материальные запасы, логистический поход, предприятие, модели управления запасами.

(С) Швець Ю.О., 